\title{
GAMBARAN STATUS KEBERSIHAN RONGGA MULUT DAN STATUS GINGIVA PADA MAHASISWA DENGAN GIGI BERJEJAL
}

\author{
${ }^{1}$ Altriany Sasea \\ ${ }^{2}$ B. S. Lampus \\ ${ }^{3}$ Aurelia Supit \\ ${ }^{1}$ Kandidat skripsi Program Studi Kedokteran Gigi Fakultas Kedokteran \\ Universitas Sam Ratulangi Manado \\ ${ }^{2}$ Bagian Ilmu Kesehatan Lingkungan Fakultas Kedokteran \\ Universitas Sam Ratulangi Manado \\ ${ }^{3}$ Bagian Ilmu Penyakit Mulut Program Studi Kedokteran Gigi Fakultas Kedokteran \\ Universitas Sam Ratulangi Manado \\ Email: alien_getoo@yahoo.co.id
}

\begin{abstract}
Dental crowding is a condition which the position of the teeth are outside the normal tooth arrangement. This condition occasionally become problem for patient. Based from function, dental crowding is very hard to clean with tooth brush, it can accumulated plaque, which is one of the risk factor of bad oral hygiene, calculus and gingivitis. This study objectives was the find out overview of oral hygiene and gingival status of college student who had crowding teeth in Dentistry Courses Medical Faculty of Sam Ratulangi University Manado. This is a descriptive study. Population study was all college student who had crowding teeth in Dentistry Courses Medical Faculty of Sam Ratulangi University Manado. Samples were 40 person ad sampling method was total sampling. The results oral hygiene using Simplified Oral Hygiene Index (OHI-S) in the crowding of both jaws showed that the majority of $66.67 \%$ of the study have good oral hygiene and gingival status of research results by using the gingival index in both jaws partial crowding $65.22 \%$ of the study subjects had mild inflammation of gingival status.
\end{abstract}

Keywords: Dental crowding, Oral hygiene, gingival status.

Abstrak: Gigi berjejal merupakan keadaan berjejalnya gigi di luar susunan gigi yang normal. Kondisi gigi berjejal terkadang menjadi masalah bagi penderitanya. Gigi berjejal sangat sulit dibersihkan dengan menyikat gigi, kondisi ini dapat menyebabkan penumpukan plak yang juga merupakan salah satu faktor resiko terjadinya kalkulus dan gingivitis. Penelitian ini bertujuan mengetahui gambaran status kebersihan rongga mulut dan status gingiva pada mahasiswa dengan gigi berjejal di Program Studi Kedokteran Gigi Fakultas Kedokteran Universitas Sam Ratulangi Manado. Penelitian ini merupakan penelitian deskriptif. Populasi penelitian ini yaitu mahasiswa yang memiliki kondisi gigi berjejal di Program Studi Kedokteran Gigi Fakultas Kedokteran Universitas Sam Ratulangi Manado. Sampel berjumlah 40 orang dan pengambilan sampel dilakukan dengan metode total sampling. Hasil penelitian kebersihan rongga mulut dengan menggunakan Oral Hygiene Index Simplified (OHI-S) pada gigi berjejal kedua rahang menunjukkan bahwa sebagian besar 66,67\% subjek penelitian memiliki kebersihan mulut baik dan hasil penelitian status gingiva dengan menggunakan indeks gingiva pada gigi berjejal kedua rahang sebagian besar 65,22\% subjek penelitian memiliki status gingiva inflamasi ringan.

Kata kunci: Gigi berjejal, status kebersihan rongga mulut, status gingiva. 
Hasil Survei Kesehatan Rumah Tangga (SKRT) tahun 2010 Departemen Kesehatan RI menunjukkan bahwa $63 \%$ penduduk Indonesia menderita penyakit gigi dan mulut meliputi karies gigi dan penyakit jaringan penyangga. ${ }^{1}$ Kesehatan gigi dan mulut sangat penting, peranannya cukup besar dalam mempersiapkan zat makanan sebelum absorbsi nutrisi pada saluran pencernaan, disamping fungsi estetis dan bicara.Berbagai penyakit maupun kelainan gigi dan mulut dapat menggangu penampilan, fonetik ataupun pengunyahan. Salah satu kelainan susunan gigi disebut dengan maloklusi. ${ }^{2}$

Maloklusi merupakan bentuk hubungan rahang atas dan rahang bawah yang menyimpang dari bentuk standar yang diterima sebagai bentuk normal.Maloklusi dapat disebabkan karena tidak ada keseimbangan dentofasial. Keseimbangan dentofasial ini tidak disebabkan oleh satu faktor saja, tetapi beberapa faktor saling mempengaruhi. ${ }^{3,4} \quad$ Faktor-faktor yang mempengaruhi maloklusi menurut Salzman dibagi atas faktor prenatal dan postnatal. Faktor prenatal terdiri dari genetik, diferensiasi dan kongental. Faktor postnatal terdiri dari perkembangan, fungsional dan lingkungan. ${ }^{3}$ Prevalensi maloklusi tahun 2008 mencapai 80\% dan menduduki urutan ketiga setelah karies dan penyakit periodontal. ${ }^{5}$ Jenis-jenis maloklusi yang dapat dijumpai antara lain protrusi, intrusi dan ekstrusi, crossbite, open bite, gigi berjejal, dan diastema. Jenis-jenis maloklusi tersebut, salah satu yang menjadi acuan penelitian yaitu gigi berjejal merupakan komponen prevalensi maloklusi tertinggi pada pasien-pasien kedokteran gigi. Hal tersebut dapat dilihat dari penelitian di Departemen Ortodonti FKG-UI tahun 1999 di Jakarta yang melaporkan dari 270 sampel pada anak usia 12-14 tahun ditemukan gigi berjejal sebesar 44,9\%, gigi renggang (diastema) 16,7\%, gigi mendongos (protrusi) 6,3\%, tumpang gigit dalam (deep bite) $6,3 \%$, gigitan silang (scissor bite) $12,3 \%$, dan gigitan terbuka (open bite) 13,2 \%. ${ }^{5}$

Gigi berjejal merupakan keadaan berjejalnya gigi di luar susunan gigi yang normal. $^{5}$ Susunan gigi yang berjejal-jejal jarang terjadi pada gigi-geligi susu. Susunan semacam ini lebih sering terlihat pada gigigigi tetap, dimana hal ini biasa ditemukan pada lebih dari $60 \%$ populasi dewasa di Inggris. ${ }^{6}$ Kondisi gigi berjejal terkadang menjadi masalah bagi penderitanya. Gigi berjejal sangat sulit dibersihkan dengan menyikat gigi, kondisi ini dapat menyebabkan penumpukan plak yang juga merupakan salah satu faktor resiko terjadinya gingivitis. Hal ini dapat disebabkan oleh karena pada saat pembersihan gigi atau menyikat gigi, sikat gigi sulit menjangkau sisa makanan yang menempel pada daerah interdental gigi berjejal sehingga terjadi akumulasi plak dan membentuk kalkulus kemudian menjadi pemicu gigi berlubang (karies) dan penyakit gusi (gingivitis) bahkan kerusakan jaringan pendukung gigi (periodontitis) sehingga gigi menjadi goyang dan terpaksa harus dicabut. ${ }^{7}$

Penelitian ini akan dilakukan pada mahasiswa program Studi Kedokteran Gigi Universitas Sam Ratulangi, dimana survei awal ditemukan pada beberapa mahasiswa terdapat kondisi gigi berjejal untuk memperoleh data dan gambaran tentang keluhan dalam kaitannya dengan kesulitan dalam membersihkan sisa makanan yang tersangkut pada gigi berjejal yang sulit dijangkau oleh sikat gigi. Mahasiswa kedokteran gigi sebagai calon dokter gigi dengan pengetahuan yang dimiliki seharusnya lebih memiliki kesadaran untuk menjaga kebersihan rongga mulut serta dapat memberikan informasi dan berbagi pengetahuan kepada masyarakat luas tentang pentingnya menjaga kebersihan rongga mulut sehingga dapat mencegah penyakit rongga mulut yang timbul pada masyarakat.

Berdasarkan latar belakang, penulis tertarik melakukan penelitian mengenai gambaran status kebersihan rongga mulut dan status gingiva pada gigi berjejal dalam hal ini peneliti menggunakan sampel mahasiswa Program Studi Kedokteran Gigi Fakultas Kedokteran Universitas Sam Ratulangi angkatan tahun 2008-2011. 
54 Jurnal e-GiGi (eG), Volume 1, Nomor 1, Maret 2013, hlm. 52-58

\section{METODE PENELITIAN}

Penelitian ini merupakan penelitian deskriptif. Penelitian dilaksanakan di Kampus Program Studi Kedokteran Gigi Universitas Sam Ratulangi Manado pada tanggal 16 bulan Oktober - November 2012. Populasi pada penelitian ini yaitu semua mahasiswa gigi berjejal di Program Studi Kedokteran Gigi Fakultas Kedokteran Universitas Sam Ratulangi Manado berjumlah 62 orang. Kriteria inklusi Mahasiswa Program Studi Kedokteran Gigi UNSRAT yang memiliki kondisi gigi berjejal, bersedia menjadi subjek penelitian, bersedia mengisi informed consent dan kooperatif dalam pengambilan data. Mahasiswa yang sedang menggunakan alat ortodonsi cekat dimasukkan dalam kriteria eksklusi. Teknik pengambilan sampel yang digunakan total sampling yaitu semua anggota populasi yang memenuhi kriteria inklusi menjadi sampel penelitian. Besar sampel ialah seluruh anggota populasi, yakni keseluruhan mahasiswa dengan gigi berjejal di Program Studi Kedokteran Gigi Fakultas Kedokteran Universitas Sam Ratulangi Manado angkatan 2008-2011 berjumlah 40 orang. Variabel penelitian ini yaitu status kebersihan rongga mulut dan status gingiva.

Pemeriksaan status kebersihan rongga mulut adalah suatu keadaan atau kondisi kebersihan gigi dan mulut yang menggambarkan kebersihan mulut baik, sedang atau buruk. Indeks yang digunakan pada penelitian ini untuk menilai kebersihan mulut yaitu Oral Hygiene Index Simplified (OHIS) menurut Greene dan Vermilion. Permukaan gigi yang diperiksa adalah enam permukaan gigi, yaitu empat permukaan gigi posterior dan dua permukaan gigi anterior. Pada bagian posterior, permukaan gigi yang digunakan : molar pertama atau molar dua. Permukaan yang diperiksa molar atas pada sisi bukal dan molar bawah pada sisi lingual. Pada bagian anterior, permukaan gigi yang digunakan: Permukaan labial dari incisivus satu kanan atas dan Insisivus satu kiri bawah. Jika kedua gigi anterior itu tidak ada, maka digantikan insisivus satu (21atau 41 berturut-turut) pada sisi berlawanan dari midline.
Rumus Perhitungan OHI-S:

$$
\begin{aligned}
& \text { OHI-S = DI + CI } \\
& \text { DI: Debris Indeks } \\
& \text { CI: Kalkulus Indeks }
\end{aligned}
$$

Penilaian OHI-S; Baik, bila nilai berada di antara 0-1,2; Sedang, bila nilai berada di antara 1,3-3,0; Buruk, bila nilai berada di antara 3,1-6,0.

Status gingiva yang diperiksa adalah gingiva yang mengelilingi gigi molar kanan dan kiri atas bagian bukal, gigi insisivus kanan atas bagian labial, gigi molar kanan dan kiri bawah bagian lingual dan insisivus kiri bawah bagian labial. Status gingiva adalah suatu keadaan atau kondisi kesehatan gingiva yang menggambarkan gingiva dalam keadaan normal, gingiva dengan inflamasi ringan, sedang, dan berat yang diukur berdasarkan skor indeks gingiva menurut Loe dan Silness. dengan kriteria; $0=$ Gingiva normal tidak ada keradangan, tidak ada perubahan warna, tidak ada perdarahan; $1=$ Peradangan ringan : terlihat ada sedikit perubahan warna, dan sedikit edema tetapi tidak ada perdarahan saat probing; 2=Peradangan sedang: warna kemerahan, adanya edema, dan terjadi perdarahan saat probing; 3=Peradangan berat: warna merah terang atau merah menyala, adanya edema, ulserasi, kecenderungan adanya perdarahan spontan.

Rumus indeks gingiva: Indeks Gingiva

$(\mathrm{GI})=\frac{\text { Total Skor }}{\Sigma \text { gigi yang diperiksa }}$

Keparahan inflamasi gingiva dapat ditentukan dari skor indeks gingiva dengan kriteria sebagai berikut; Inflamasi ringan, bila skor indeks gingiva berada di antara 0,1-10, Inflamasi sedang, bila skor indeks gingiva berada di antara 1,1-2,0, Inflamasi berat, bila skor indeks gingiva berada di antara 2,1-3,0.

Gigi berjejal anterior dan posterior yang memiliki penyimpangan posisi mahkota gigi termasuk gigi yang tumpang tindih, gigi berkelompok, rotasi dan gigi 
yang tidak terletak pada lengkung gigi. Kriteria gigi berjejal berdasarkan Dental Aesthetic Indeks yaitu; Skor $0=$ bila tidak ada berjejal; Skor 1=bila pada salah satu rahang ada berjejal; Skor 2=bila pada kedua rahang berjejal.

Instrument yang digunakan dalam penelitian yaitu formulir pemeriksaan OHIS dan Gingiva Indeks. Alat dan bahan yang digunakan yaitu Alat diagnostik, periodontal probe, Masker dan handskoen, Senter, Alkohol dan kapas, Air dan sabun, Disclosing solution.

Pengumpulan data dilakukan melalui Pertimbangan etik Sebelum melakukan penelitian subjek penelitian telah dimintakan izin tertulis berupa informed consent. Pengambilan data berupa data Oral Hygiene Index Simplified (OHI-S) dan data Gingiva Index yang diperoleh dengan melakukan pemeriksaan langsung didalam rongga mulut menggunakan alat diagnostik dan hasil pemeriksaan langsung pada lembar formulir pemeriksaan. Analisis data yang digunakan dalam penelitian ini ialah secara deskriptif. Data di olah dan dideskripsikan dalam bentuk tabel, kemudian dianalisis berdasarkan hasil persentase.

\section{HASIL PENELITIAN}

Penelitian ini dilaksanakan di kampus
Program Studi Kedokteran Gigi Universitas Sam Ratulangi yang merupa-kan salah satu Program Studi dibawah naungan Fakultas Kedokteran. Jumlah mahasiswa angkatan tahun 2008-2011 yakni sebanyak 380 orang terdiri dari laki-laki berjumlah 112 orang dan perempuan berjumlah 268 orang. Subjek penelitian yang didapatkan berdasarkan kriteria inklusi yang memiliki gigi berjejal berjumlah 40 orang dan distribusi berdasarkan jenis kelamin (Tabel 1).

Tabel 1 menunjukkan subjek penelitian berdasarkan jenis kelamin pada mahasiswa perempuan dengan gigi berjejal pada satu rahang sebesar 52,95\% dibanding dengan mahasiswa laki-laki 47,05\%. Subjek penelitian pada mahasiswa perempuan dengan gigi berjejal pada kedua rahang sebesar 69,56\% dibanding dengan mahasiswa laki-laki 30,45.

Distribusi hasil penelitian ini dapat dibagi menjadi dua, yaitu pemeriksaan kebersihan rongga mulut pada satu rahang gigi berjejal dan dua rahang gigi berjejal (Tabel 2).

Berdasarkan Tabel 2, hasil pemeriksaan OHI-S pada gigi berjejal satu rahang menunjukkan bahwa sebagian besar (56,25\%) subjek penelitian memiliki kebersihan rongga mulut baik, sedangkan subjek penelitian yang tersisa memiliki kebersihan mulut sedang $43,75 \%$ dan tidak

Tabel 1. Distribusi subjek penelitian berdasarkan jenis kelamin

\begin{tabular}{ccccccc}
\hline \multirow{2}{*}{ Gigi berjejal } & \multicolumn{4}{c}{ Jenis kelamin } & \multicolumn{2}{c}{ Total } \\
& \multicolumn{2}{c}{ Laki - laki } & \multicolumn{2}{c}{ Perempuan } & & \\
& $\mathrm{N}$ & $\%$ & $\mathrm{n}$ & $\%$ & $\mathrm{n}$ & $\%$ \\
\hline Pada satu rahang & 8 & 47,05 & 9 & 52,95 & 17 & 100 \\
Pada dua rahang & 7 & 30,45 & 16 & 69,56 & 23 & 100 \\
\hline
\end{tabular}

Tabel 2. Distribusi status kebersihan rongga mulut dengan gigi berjejal

\begin{tabular}{|c|c|c|c|c|c|c|c|c|}
\hline \multirow{3}{*}{ Gigi berjejal } & \multicolumn{6}{|c|}{ OHI-S } & \multicolumn{2}{|c|}{ Total } \\
\hline & & aik & & ang & & & & \\
\hline & $\mathrm{n}$ & $\%$ & $\mathrm{n}$ & $\%$ & $\mathrm{n}$ & $\%$ & $\mathrm{n}$ & $\%$ \\
\hline Pada satu rahang & 9 & 56,25 & 7 & 43,75 & 0 & 0 & 16 & 100 \\
\hline Pada dua rahang & 6 & 25 & 16 & 66,67 & 2 & 8,33 & 24 & 100 \\
\hline
\end{tabular}


56 Jurnal e-GiGi (eG), Volume 1, Nomor 1, Maret 2013, hlm. 52-58

Tabel 10. Distribusi status gingiva

\begin{tabular}{|c|c|c|c|c|c|c|c|c|}
\hline \multirow{3}{*}{ Gigi berjejal } & \multicolumn{6}{|c|}{ Status gingiva } & \multicolumn{2}{|c|}{ Total } \\
\hline & \multicolumn{2}{|c|}{ Normal } & \multicolumn{2}{|c|}{$\begin{array}{c}\text { Inflamasi } \\
\text { ringan }\end{array}$} & \multicolumn{2}{|c|}{$\begin{array}{c}\text { Inflamasi } \\
\text { sedang }\end{array}$} & & \\
\hline & $\mathrm{n}$ & $\%$ & $\mathrm{n}$ & $\%$ & $\mathrm{n}$ & $\%$ & $\mathrm{n}$ & $\%$ \\
\hline Pada satu rahang & 9 & 52,95 & 8 & 47,05 & 0 & 0 & 17 & 100 \\
\hline Pada dua rahang & 4 & 17,39 & 15 & 65,22 & 4 & 17,39 & 23 & 100 \\
\hline
\end{tabular}

terdapat subjek penelitian dengan kebersihan mulut buruk. Subjek penelitian yang memiliki gigi berjejal pada kedua rahang sebagian besar (66,67\%) dengan

Distribusi hasil penelitian berdasarkan indeks gingiva pada subjek penelitian dapat dibagi dalam tiga kelompok yaitu subjek penelitian dengan keadaan gingiva yang normal, memiliki inflamasi ringan dan inflamasi sedang (Tabel 10).

Berdasarkan tabel di atas, hasil pemeriksaan status gingiva pada gigi berjejal satu rahang menunjukkan bahwa sebagian besar $(52,94 \%)$ subjek penelitian memiliki gingiva normal, sedangkan subjek penelitian yang tersisa memiliki inflamasi ringan $47,05 \%$ dan tidak terdapat subjek penelitian yang memiliki inflamasi sedang. Subjek penelitian yang memiliki gigi berjejal pada dua rahang $(65,22 \%)$ dengan status gingiva inflamasi ringan, sedangkan pada subjek penelitian yang tersisa memiliki gingiva normal 17,39\% dan yang memiliki status gingiva inflamasi sedang $17,39 \%$.

\section{BAHASAN}

Hasil pemeriksaan kebersihan rongga mulut dengan menggunakan Oral Hygiene Index Simplified (OHI-S) pada gigi berjejal satu rahang menunjukkan bahwa sebagian besar $(56,25 \%)$ subjek penelitian memiliki kebersihan mulut baik (Tabel 9). Hal ini disebabkan karena pada mahasiswa yang memiliki gigi berjejal dengan satu rahang lebih mudah dibersihkan dan adanya kepedulian serta usaha dalam menjaga kebersihan mulutnya sendiri. Kebersihan rongga mulut yang terjaga dengan baik mampu meningkatkan kesehatan rongga mulut. Kebersihan rongga mulut dan gigi status kebersihan mulut sedang, sedangkan subjek penelitian memiliki kebersihan mulut baik 25\% dan subjek penelitian yang tersisa memiliki kebersihan mulut buruk 8,33\%.

bertujuan untuk mencegah terbentuknya plak, maka dibutuhkan perawatan kebersihan rongga mulut secara teratur dan mahasiswa lebih lagi memerhatikan kebersihan rongga mulut.

Subjek penelitian yang memiliki gigi berjejal pada kedua rahang sebagian besar (66,67\%) dengan status kebersihan mulut sedang (Tabel 9). Peneliti berasumsi bahwa hal ini disebabkan karena gigi berjejal terutama pada kedua rahang merupakan salah satu faktor yang memengaruhi sulitnya pemeliharaan kebersihan mulut. Hal ini disebabkan karena pada saat menyikat gigi, sikat gigi sulit menjangkau sisa makanan yang menempel pada daerah interdental gigi yang berjejal sehingga mengakibatkan akumulasi plak dan membentuk kalkulus. Penelitian ini memiliki kesamaan dengan penelitian yang dilakukan oleh Dalva Maria tahun 2004 tentang evaluasi indeks periodontal dari gingiva dan plak dengan gigi berjejal dalam perkembangan gingivitis di Brazil. Tingkat kebersihan mulut pada subjek penelitian termasuk pada kategori sedang. Hasil penelitian ini juga menunjukkan adanya hubungan yang signifikan antara gigi berjejal, plak, kalkulus dan peradangan gingiva. ${ }^{9}$

Kebersihan mulut juga dapat dipengaruhi oleh perilaku pemeliharaan kebersihan mulut. Pembentukan perilaku dapat diperoleh dari lingkungan berupa pengalaman dari kehidupan sehari-hari. ${ }^{9}$

Mahasiswa kedokteran gigi telah memiliki pengetahuan tentang kebersihan gigi dan mulut. Hal ini dapat memengaruhi 
perilaku kebersihan gigi dan mulut dari mahasiswa. Namun, hasil penelitian kebersihan mulut pada mahasiswa yang dijadikan subjek penelitian ini ditemukan berada pada tingkat kebersihan mulut sedang. Peneliti berasumsi bahwa mahasiswa belum berhasil menerapkan pengetahuan tentang kesehatan gigi dan mulut pada kebersihan mulutnya sendiri. Kemampuan untuk memelihara diri agar dapat mencapai tingkat kebersihan mulut yang baik adalah kondisi yang memacu tinggi atau rendahnya status kebersihan mulut.

Hasil penelitian tentang status gingiva pada mahasiswa dengan gigi berjejal pada satu rahang menunjukkan bahwa sebagian besar (52,94\%) subjek penelitian memiliki gingiva normal (Tabel 10). Hal ini disebabkan karena upaya dari mahasiswa dalam menjaga dan memelihara kebersihan rongga mulutnya sendiri. Kebersihan rongga mulut ialah usaha mempertahankan atau menjaga kebersihan dan kesehatan rongga mulut dan gigi dengan menggosok gigi dan flossing untuk membantu dalam mengangkat plak dan sisa makanan diantara gigi untuk mengurangi inflamasi gingiva. ${ }^{10}$

Subjek penelitian yang memiliki gigi berjejal pada dua rahang sebagian besar $(65,22 \%)$ dengan status gingiva inflamasi ringan (Tabel 10). Peneliti berasumsi bahwa kesulitan dalam menjaga kebersihan gigi dan mulut pada subjek penelitian dengan gigi berjejal kususnya pada kedua rahang dapat memicu adanya penumpukan plak yang menyebabkan terjadinya inflamasi gingiva pada rongga mulut. Kesulitan dalam prosedur menyikat gigi memungkinkan adanya interdental gigi yang tidak dapat dibersihkan dengan baik yang pada akhirnya menyebabkan retensi sisa makanan dan plak. Plak yang terbentuk dari sisa makanan akan membentuk kalkulus. Kalkulus tebentuk dari plak bakteri yang telah mengalami mineralisasi yang melekat pada permukaan gigi dan tepi gingiva, bakteribakteri mengeluarkan toksin dan menyerang gingiva sehingga menyebabkan peradangan pada gingiva. Hasil penelitian ini memiliki kesamaan dengan penelitian yang dilakukan oleh Dalva Maria tahun 2004 tentang evaluasi indeks periodontal dari gingiva dan plak dengan gigi berjejal dalam pengembangan gingivitis di Brazil yang menunjukkan bahwa sebagian besar subjek penelitian menunjukan status gingiva dengan inflamasi ringan. Penelitian tersebut juga memaparkan bahwa gigi berjejal tidak memberi pengaruh yang berarti apabila kebersihan rongga mulut pasien termasuk pada kategori baik. ${ }^{9}$ Peneliti berasumsi bahwa kebersihan mulut pada subjek penelitian yang termasuk pada mahasiswa dengan gigi berjejal sebagian besar memiliki status kebersihan mulut sedang sehingga memungkinkan terbentuknya inflamasi gingiva ringan. Hal ini terjadi pada subjek penelitian yang memiliki gigi berjejal pada kedua rahang karena prosedur kebersihan mulut lebih sulit dilakukan pada subjek penelitian pada kondisi tersebut.

\section{SIMPULAN DAN SARAN}

Berdasarkan hasil penelitian, dapat disimpulkan Gambaran status kebersihan rongga mulut pada mahasiswa kedokteran gigi dengan gigi berjejal termasuk pada kategori kebersihan rongga mulut sedang (66,67\%) dan Gambaran status gingiva pada mahasiswa kedokteran gigi dengan gigi berjejal termasuk pada kategori inflamasi ringan (65,22\%). Saran Bagi mahasiswa kedokteran gigi dengan gigi berjejal, kiranya lebih memerhatikan kebersihan rongga mulut dan melakukan perawatan ortodonsi serta perlu penelitian lebih lanjut untuk melihat status kebersihan rongga mulut dan status gingiva pada gigi berjejal dengan faktor-faktor lain yang memengaruhi.

\section{UCAPAN TERIMA KASIH}

Penulis mengucapkan terima kasih kepada drg. P.S Anindita, Sp Orto (Dosen penguji I) dan drg. Vonny N. S. Wowor, MKes (Dosen penguji II) atas masukan yang telah diberikan kepada penulis. Penulis juga mengucapkan terima kasih kepada semua pihak yang telah membantu penulis dalam menemukan ide dalam penulisan karya tulis ini. 
58 Jurnal e-GiGi (eG), Volume 1, Nomor 1, Maret 2013, hlm. 52-58

\section{DAFTAR PUSTAKA}

1. Survei kesehatan rumah tangga (SKRT) [homepage on the Internet]. 2010 [cited 2012 Aug 04]. Available from: http://www.ilmukesehatangigi.com/2010/1 1/02//keadaan-dan-masalah-kesehatan-gigidan-mulut-di-indonesia.

2. Oktaviani D. Analisis hubungan maloklusi dengan kualitas hidup pada remaja SMU kota Medan tahun 2007. Jurnal ilmiah kedokteran gigi USU. 2008:1.

3. Salzman JA. Etiology of malocclusion and dentofacial deformities. In: practice of orthodontics. Philadelphia and montreal: JB Lippincott company, 1966; p.114-123,378386.

4. Sulastry S. Korelasi antara lebar mesiodistal gigi dengan kecembungan profil jaringan lunak wajah orang Bugis-Makasar Jurnal Dentofacial. 2007;6(2):72-7.

5. Susanto C. Need dan demand serta akibat dari maloklusi pada siswa SMU Negeri I Binjai. Jurnal ilmiah kedokteran gigi USU. 2010:6.

6. Foster TD. Buku Ajar Ortodonsi (Edisi
Ketiga). Jakarta: EGC, 1997; p.131.

7. Wijaya S. Perbandingan gigi dan dimensi lengkung antara gigi tanpa berjejal dengan berjejal. Jurnal ilmiah kedokteran gigi USU. 2011:1-6.

8. Hapsari SL. Perawatan dasar gingivitis pada anak [homepage on the Internet]. 2012 [cited 2012 Mar 22]. Available from: URL:http//respository.USU.ac.id. h.1-2

9. Dalva M. Evaluation of periodontal index of gingival and plaque with dental crowding in development of gingivitis in children and adolescents [Serial online]. 2004 [cited 2012 Nov]. Available from: http:http://univille.edu.br/community/depto _odontologia/VirtualDisk.html?action=dow nloadFile\&file=avaliacao_indice_gengival. pdf\&current=\%2FODONTOLOGIA\%2FR SBO\%2FRSB_v.1_n.1_novembro_2004; p.20.

10. Herijulianti E, Tati SI, Sri A. Pendidikan kesehatan gigi. Jakarta: Penerbit Buku Kedokteran EGC, 2001; p.35, 98.

11. Potter AP, Perry AG. Buku ajar fundamental keperawatan: konsep, proses dan praktik. Jakarta: EGC, 2005; p.1376. 